\title{
$\mathrm{YBa}_{2} \mathrm{Cu}_{3} \mathrm{O}_{7-y}$ 超伝導体の前駆体としての金属酢酸塩ゲルの熱分解
}

\author{
梅田鉄・幸塚広光・作花済夫 \\ (京都大学化学研究所, 611 京都府宇治市五ヶ庄)
}

\section{Thermal Decomposition of Metal Acetate Gel as a Precursor of $\mathrm{YBa}_{2} \mathrm{Cu}_{3} \mathrm{O}_{7-y}$ Superconductor}

Tetsu UMEDA, Hiromitsu KOZUKA and Sumio SAKKA

(Institute for Chemical Research, Kyoto University, Uji-shi, Kyoto

611)

\begin{abstract}
A metal acetate gel as a precursor of $\mathrm{YBa}_{2} \mathrm{Cu}_{3} \mathrm{O}_{7-y}$ superconductor bloats in the range of $200^{\circ}-300^{\circ} \mathrm{C}$ during heat treatment for conversion of the gel into a superconducting ceramic, becoming a porous and deformed product, when the heating rate is $5^{\circ} \mathrm{C} / \mathrm{min}$. In order to minimize the pore formation and deformation, the mechanism of bloating and the change of microstructure of the gel were investigated by thermal analysis, X-ray diffraction technique, infrared spectroscopy and mass spectroscopy of evolving gases. It was confirmed that the gel is composed of weak bonds between metal ions through acetate ions and that the sintering process includes elimination of water, thermal decomposition of metal acetates and reaction of precipitated intermediate species. It was also found that the bloating is caused mainly by abrupt thermal decomposition of acetate ions bonding with copper ions. Lower heating rates such as $0.0833-0.167^{\circ} \mathrm{C} / \mathrm{min}\left(5-10^{\circ} \mathrm{C} / \mathrm{h}\right)$ for the heat treatment of gel fibers were found to be effective in converting them into dense ceramic fibers by lowering the rate of thermal decomposition of acetate ions and by suppressing severe bloating.

[Received February 2, 1990 ; Accepted April 13, 1990]
\end{abstract}

Key-words : Superconducting oxide, Fiber, Sol-gel method, Acetate, Thermal decomposition, Mass spectrometry

\section{1. 緒言}

高温超伝導セラミックスの作製方法の一つとしてゾル ゲル法がある。この方法では，原料物質を溶媒に溶かし た出発溶液が低粘性状態のゾル，高粘性状態のゾル，固 化したゲルの状態を経るので，セラミックスをファイ バーや薄膜として得ることが可能である ${ }^{1) \sim 11) 。 ~}$

著者らは，金属䣷酸塩水溶液を出発溶液とし，粘性ゾ ルから紡糸したゲルファイバーを加熱することによって $\mathrm{YBa}_{2} \mathrm{Cu}_{3} \mathrm{O}_{7-y}$ 超伝導ファイバーが得られることを報告

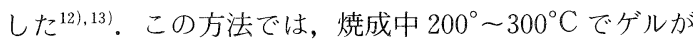
軟化し，更にゲル中の化合物の分解によって発生する気 体によって発泡がおこるため, 得られた超伝導ファイ バーは中空構造を持ち, 強度が小さい。したがって, 特 性の優れた緻密な焼結体を得るにはゲルの微細構造や発 泡の機構を明らかにし，発泡を抑制する手段を講じるこ とが必要である。

本研究では，発泡の機構を明らかにして発泡を抑制す る手段を見いだすために熱分析，X線回折，赤外分光， 質量分析計を用いる発生気体の分析によってゲルの熱分 解過程を調べた。

更に，これらの測定に基づいて中実のセラミックファ
イバーの作製を試みた。増田と建石は金属アルコキシド を出発原料とする系で昇温速度を小さくし, 気体の発生 速度を抑制することによって中実なセラミックファイ バーが作製できることを報告している ${ }^{10)}$.

\section{1 金属酢酸塩ゲルの作製}

試薬特級の $\mathrm{Y}\left(\mathrm{CH}_{3} \mathrm{COO}\right)_{3} \cdot 4 \mathrm{H}_{2} \mathrm{O}$ (三津和化学製) $2.118 \mathrm{~g}, \mathrm{Ba}\left(\mathrm{CH}_{3} \mathrm{COO}\right)_{2}$ (和光純薬工業製) $3.200 \mathrm{~g}$, $\mathrm{Cu}\left(\mathrm{CH}_{3} \mathrm{COO}\right)_{2}$ (和光純薬工業製) $3.412 \mathrm{~g}$ を $100 \mathrm{ml}$ の イオン交換水に溶解させ, 均質で青色の溶液を作製した. この溶液の組成は, 金属についてモル比で $\mathrm{Y}: \mathrm{Ba}: \mathrm{Cu}$ $=1: 2: 3$ に相当しており，また濃度は $\mathrm{YBa}_{2} \mathrm{Cu}_{3} \mathrm{O}_{7}$ 換 算で $38 \mathrm{~g} / 1$ である. 得られた水溶液の $\mathrm{pH}$ 值は約 5.4 で あったが，アンモニア水を加えて $\mathrm{pH}$ 值を 6.0 6.1 に 調整し, 結晶が析出することなく溶液がゲル化するよう にした. $\mathrm{pH}$ の調整によって溶液の青色は更に濃くなっ た.この溶液を $60^{\circ} \mathrm{C}$ の乾燥器中で $5 \sim 7$ 日間放置し, 青色の透明なゲルを得た。

\section{2 分析及び測定}

ゲル粉末について, 理学電機製の示差熱天科 Ther- 
moflex TG 8110 を用いて熱重量測定及び示差熱分析在 行った。測定は空気中, 昇温速度 $10^{\circ} \mathrm{C} / \mathrm{min}$ の条件下で 行った.

ゲル，ならびにゲルを種々の温度まで加熱したものに ついてX線回折により析出物の同定を行った。加熱試料 はゲルを電気炉中で $5^{\circ} \mathrm{C} / \mathrm{min}$ の昇温速度で加熱し, 所 定の温度に達した時点で炉から取り出し, 空気中で急冷 することによって作製した。測定には理学電機製の RAD-IIA X 線回折計を使用した。

ゲル，ならびにゲルを種々の温度まで昇温したものに ついて赤外吸収を測定した。加熱試料はゲル粉末を示差 熱天科の電気炉中で $10^{\circ} \mathrm{C} / \mathrm{min}$ の昇温速度で加熱して作 製した。測定は $\mathrm{KBr}$ 錠剂法によって，日本分光製の $\mathrm{FT} / \mathrm{IR}-5 \mathrm{M}$ 赤外分光光度計を用いて行った。

ゲル粉末ならびに各金属酢酸塩 $\mathrm{Y}\left(\mathrm{CH}_{3} \mathrm{COO}\right)_{3} \cdot 4 \mathrm{H}_{2} \mathrm{O}$, $\mathrm{Ba}\left(\mathrm{CH}_{3} \mathrm{COO}\right)_{2}, \mathrm{Cu}\left(\mathrm{CH}_{3} \mathrm{COO}\right)_{2} \cdot \mathrm{H}_{2} \mathrm{O}$ を試料として質量 分析を行った。測定には島津製作所の TGA-40M と TG-GC/MS 質量分析計を使用した。ヘリウム雾囲気中 で試料を $20^{\circ} \mathrm{C} / \mathrm{min}$ の昇温速度で $900^{\circ} \mathrm{C}$ まで加熱し，生 成する気体を直接質量分析計に導入して測定した。

\section{3 ファイバーの作製}

ゲルファイバーは，ゲル化直前の高粘性ゾルを紡糸す ることによって作製した。得られたゲルファイバーをる つぼ上に橋渡ししたアルミナ棒に吊るし，その状態で電 気炉中で加熱し，七ラミックファイバーとした。焼成は 空気中, 昇温速度 $0.0833 \sim 0.167^{\circ} \mathrm{C} / \mathrm{min}\left(5 \sim 10^{\circ} \mathrm{C} / \mathrm{h}\right)$, 又は $5^{\circ} \mathrm{C} / \mathrm{min}$ で $900^{\circ} \sim 950^{\circ} \mathrm{C}$ まで加熱し 8〜12 時間保 持した後，炉中放冷する条件で行った。

\section{3. 結 果}

\section{1 熱分析}

図 1 に室温 $1000^{\circ} \mathrm{C}$ の範囲のゲルの示差熱分析曲線 七熱重量曲線を示す。 $240^{\circ}, 430^{\circ} \mathrm{C}$ に大きな発熱ピーク，

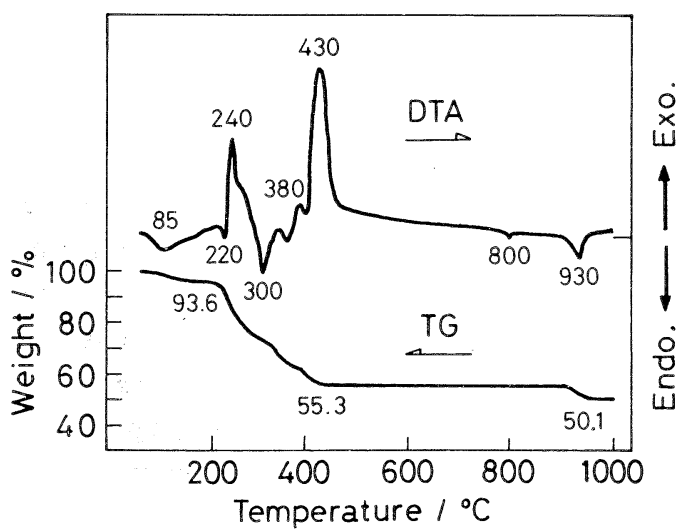

Fig. 1. DTA and TG curves for the gel as a precursor of $\mathrm{YBa}_{2} \mathrm{Cu}_{3} \mathrm{O}_{7-y}$ ceramic. The measurement was made in the ambient air. A heating rate of $10^{\circ} \mathrm{C} / \mathrm{min}$ was used. $380^{\circ} \mathrm{C}$ にさな発熱ピークがみられる。また， $85^{\circ}$, $220^{\circ}, 300^{\circ}, 800^{\circ}, 930^{\circ} \mathrm{C}$ に吸熱ピークがみられる。熱重

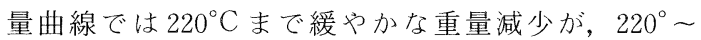
$330^{\circ} \mathrm{C}, 330^{\circ} \sim 405^{\circ} \mathrm{C}, 405^{\circ} \sim 430^{\circ} \mathrm{C}$ で 3 段階の比較的 シャープな重量減少がみられる。また， $900^{\circ} \mathrm{C}$ 以上の温 度域でも重量減少がみられる. $220^{\circ} \mathrm{C}$ までの重量損失は $6.4 \%, 220^{\circ} \sim 430^{\circ} \mathrm{C}$ 間の損失は $38.3 \%$ であり, $900^{\circ} \mathrm{C}$ 以上での重量損失は $5.2 \%$ である。

\section{$3.2 \mathrm{X}$ 線回折}

図 2 にゲル及び種々の温度まで加熱した試料のX線回 折図を示す。ゲル及び $85^{\circ} \mathrm{C}$ まで加熱した試料のピーク はブロードで，試料が非晶質であることを示している。 $220^{\circ} \mathrm{C}$ で $\mathrm{Cu}$ と $\mathrm{Cu}_{2} \mathrm{O}$ が確認され， $240^{\circ} \mathrm{C}$ ではそれらの ピーク強度は増大している. $380^{\circ} \mathrm{C}$ では $\mathrm{Cu}$ と $\mathrm{Cu}_{2} \mathrm{O}$ が 消失し, $\mathrm{CuO}$ に変化している。 $300^{\circ} \mathrm{C} て ゙ ~ B a(O H)_{2}$ が析 出し, $380^{\circ} \mathrm{C}$ で $\mathrm{BaCO}_{3}$ が析出している. $430^{\circ} \mathrm{C}$ では $\mathrm{BaCO}_{3}$ のみが確認され, $\mathrm{Ba}(\mathrm{OH})_{2}$ が $\mathrm{BaCO}_{3}$ に変化し

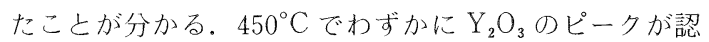
められる。

\section{3 赤外分光}

図 3 にゲル及び種々の温度まで加熱した試料の赤外吸 収スペクトルを示す。ゲルのスペクトルにおいて,

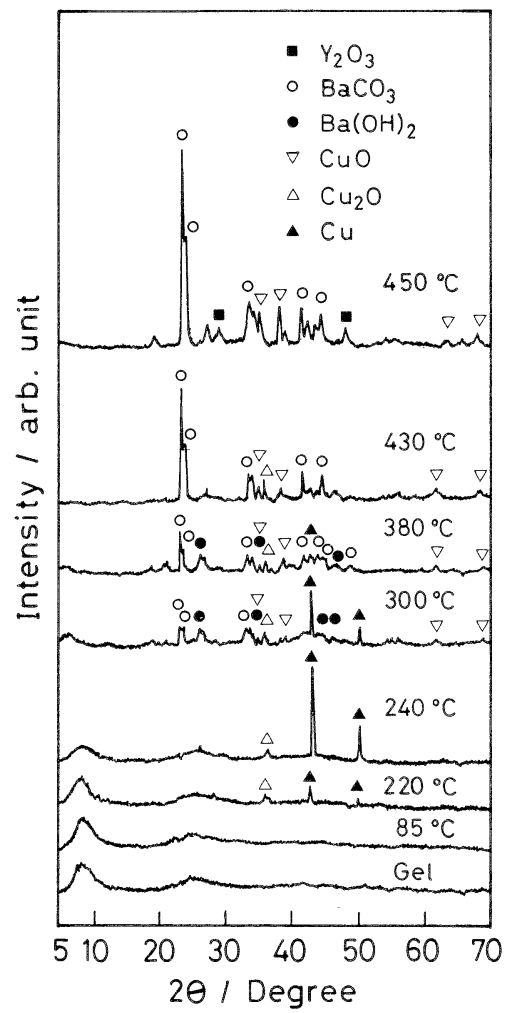

Fig. 2. X-ray diffraction patterns of the gel before and after heating to various temperatures at a rate of $5^{\circ} \mathrm{C} / \mathrm{min}$. 


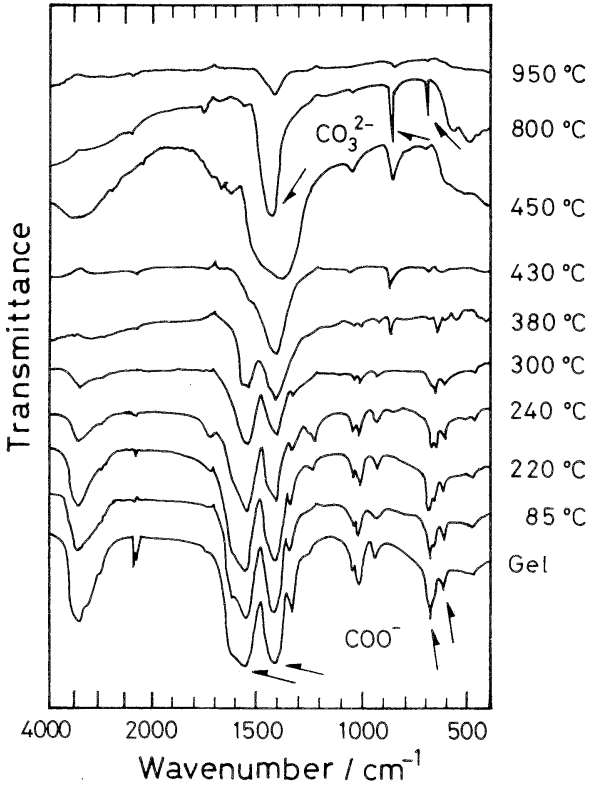

Fig. 3. Infrared absorption spectra of the gel before and after heating to various temperatures at a rate of $10^{\circ} \mathrm{C} / \mathrm{min}$ in the ambient air.

$1558,1422,660,618 \mathrm{~cm}^{-1}$ のピークはカルボキシル基, 2933,1341,1022, $471 \mathrm{~cm}^{-1}$ のピークはメチル基, その ほかの $3000 \mathrm{~cm}^{-1}$ 以上の高波数域の吸収帯と $1624 \mathrm{~cm}^{-1}$ のピークは水, $2358 \mathrm{~cm}^{-1}$ のピークは二酸化炭素による ものである。スペクトルに二酸化炭素の吸収が現れるの は，溶液のゲル化を空気中で行ったために大気中の二酸 化炭素が溶解したためである。 $\mathrm{pH}$ 調整のために加えた アンモニウムイオンの吸収ピークは明確には確認できな いが，これはアンモニウムイオンの吸収ピークがカルボ キシル基や水の吸収ピークと重なるためである.

水及び二酸化炭素の吸収ピークは温度の上昇とともに 減少する。すなわち, $2358 \mathrm{~cm}^{-1}$ の二酸化炭素の吸収ピー

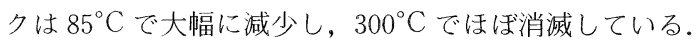
$1624 \mathrm{~cm}^{-1}$ の水の吸収ピークは $220^{\circ} \mathrm{C}$ に加熱した試料の スペクトル上ではショルダーとなり， $380^{\circ} \mathrm{C}$ でショル ダ一もほぼ消滅している。同時に $3000 \mathrm{~cm}^{-1}$ 以上の吸収 帯も消滅する. $380^{\circ} \mathrm{C}$ に加熱した試料のスペクトルには 1449, 856, $693 \mathrm{~cm}^{-1}$ につの新しいピークが現れ，炭 酸イオンが生成していることが分かる。

カルボキシル基とメチル基のピークは $430^{\circ} \mathrm{C}$ で消滅

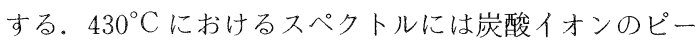
クのみが認められ， $800^{\circ} \mathrm{C}$ ではピーク強度が更に増大す

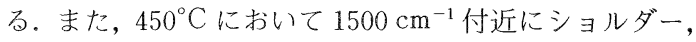
$500 \mathrm{~cm}^{-1}$ 付近に幅広い吸収帯が現れる。試料を $950^{\circ} \mathrm{C}$ まで加熱するとこれらのピークは減少，あるいは消滅する.

\section{4 発生気体の分析}

図 4 にヘリウム雲囲気中でのゲルの熱重量曲線及びゲ

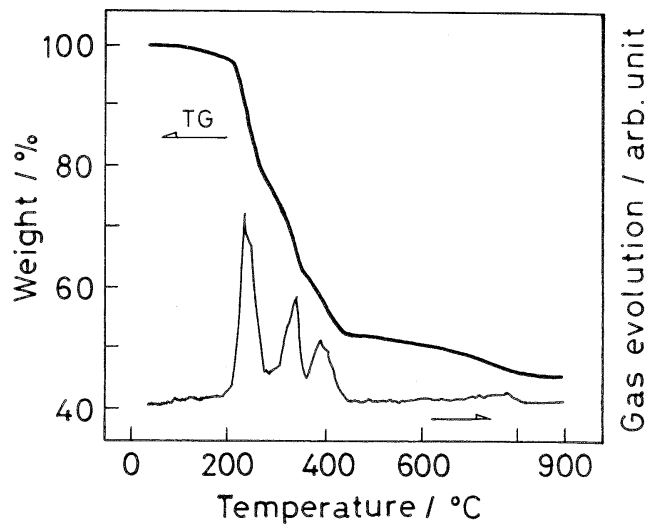

Fig. 4. TG curve and amount of gas generation during heat treatment of the gel in helium. A heating rate of $20^{\circ} \mathrm{C} / \mathrm{min}$ was used.

Table 1. Identification of gaseous compounds based on mass spectroscopy of the evolving gases.

\begin{tabular}{cl}
\hline Mass number & Chemical species \\
\hline 18 & $\mathrm{H}_{2} \mathrm{O}$ \\
28 & $\mathrm{CO}$ \\
43 & $\mathrm{CH}_{3} \mathrm{CO}$ \\
44 & $\mathrm{CO}_{2}$ or $\mathrm{N}_{2} \mathrm{O}$ \\
45 & $\mathrm{COOH}$ \\
58 & $\left(\mathrm{CH}_{3}\right)_{2} \mathrm{CO}$ \\
60 & $\mathrm{CH}_{3} \mathrm{COOH}$ \\
\hline
\end{tabular}

Temperature $/{ }^{\circ} \mathrm{C}$ $237341394 \quad 900$

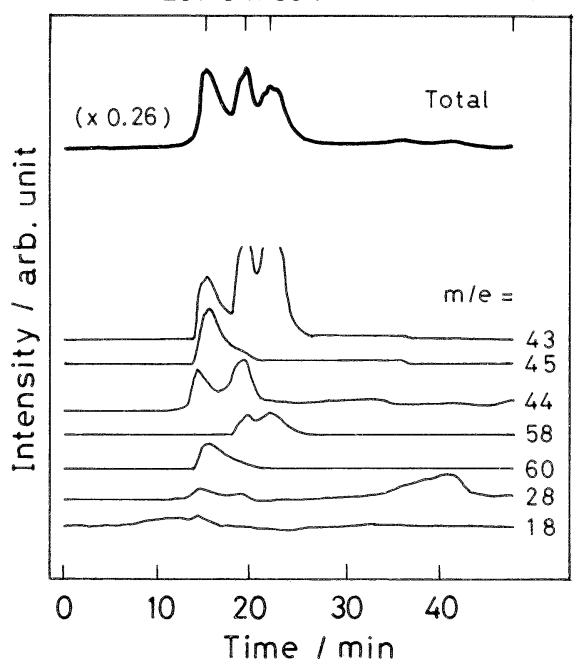

Fig. 5. Mass chromatogram of gaseous compounds having mass numbers of $18,28,43,44,45,58$ and 60 . The gel was heated at a rate of $20^{\circ} \mathrm{C} / \mathrm{min}$ in helium. The gas evolving from the sample was directly introduced into a mass spectrometer.

ルから発生する気体量の温度変化を示す. $200^{\circ} \mathrm{C}$ 以上で 4 段階の重量減少が認められ，そのうち低温側の3 段階 にはそれぞれ明確な気体発生のピークが対応している。 


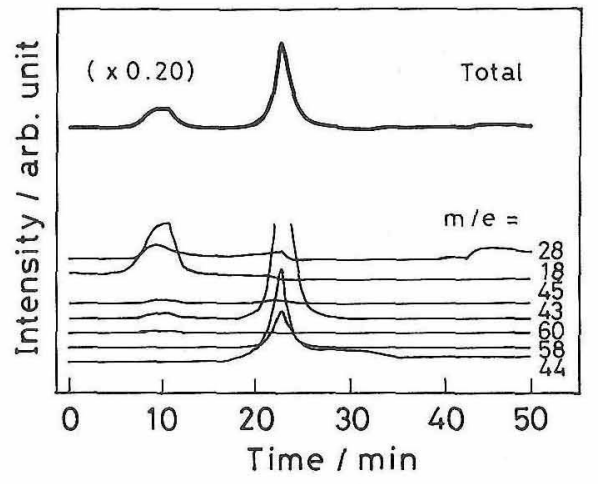

Fig.6. Mass chromatogram of gaseous compounds evolving from $\mathrm{Y}\left(\mathrm{CH}_{3} \mathrm{COO}\right)_{3} \cdot 4 \mathrm{H}_{2} \mathrm{O}$.

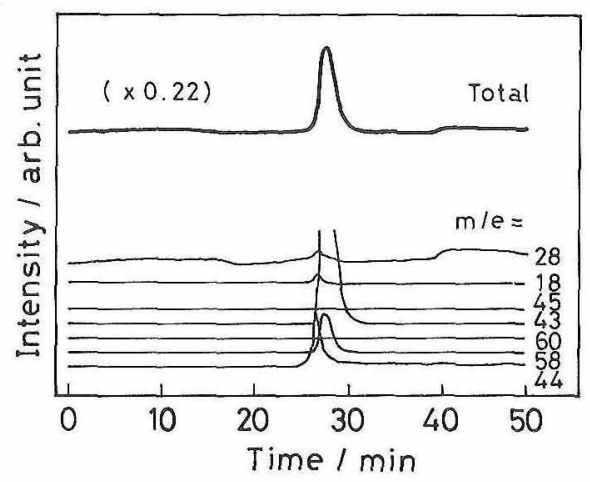

Fig. 7. Mass chromatogram of gaseous compounds evolving from $\mathrm{Ba}\left(\mathrm{CH}_{3} \mathrm{COO}\right)_{2}$.

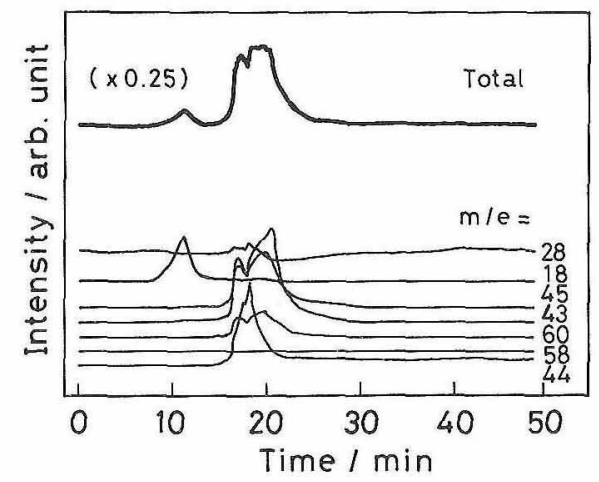

Fig. 8. Mass chromatogram of gaseous compounds evolving from $\mathrm{Cu}\left(\mathrm{CH}_{3} \mathrm{COO}\right)_{2} \cdot \mathrm{H}_{2} \mathrm{O}$.

質量分析によって，発生する気体の大部分は質量数が 18，28，43，44，45，58，60の化学種であることが確認さ れた. 出発物質が各金属の酢酸塩，水，アンモニアであ ることに基づいて，気体中の化学種を上述の質量数と対 応させた結果を流 1 に示す。

マススペクトルのピークのうち, 上記の質量数に対忘 するピークの強度を時閒の関数として表したクロマトグ ラムを図 5 に示す．単独の金属酢酸塩についての同様の クロマトグラムを図6 8に示す.いずれの金属酢酸塩
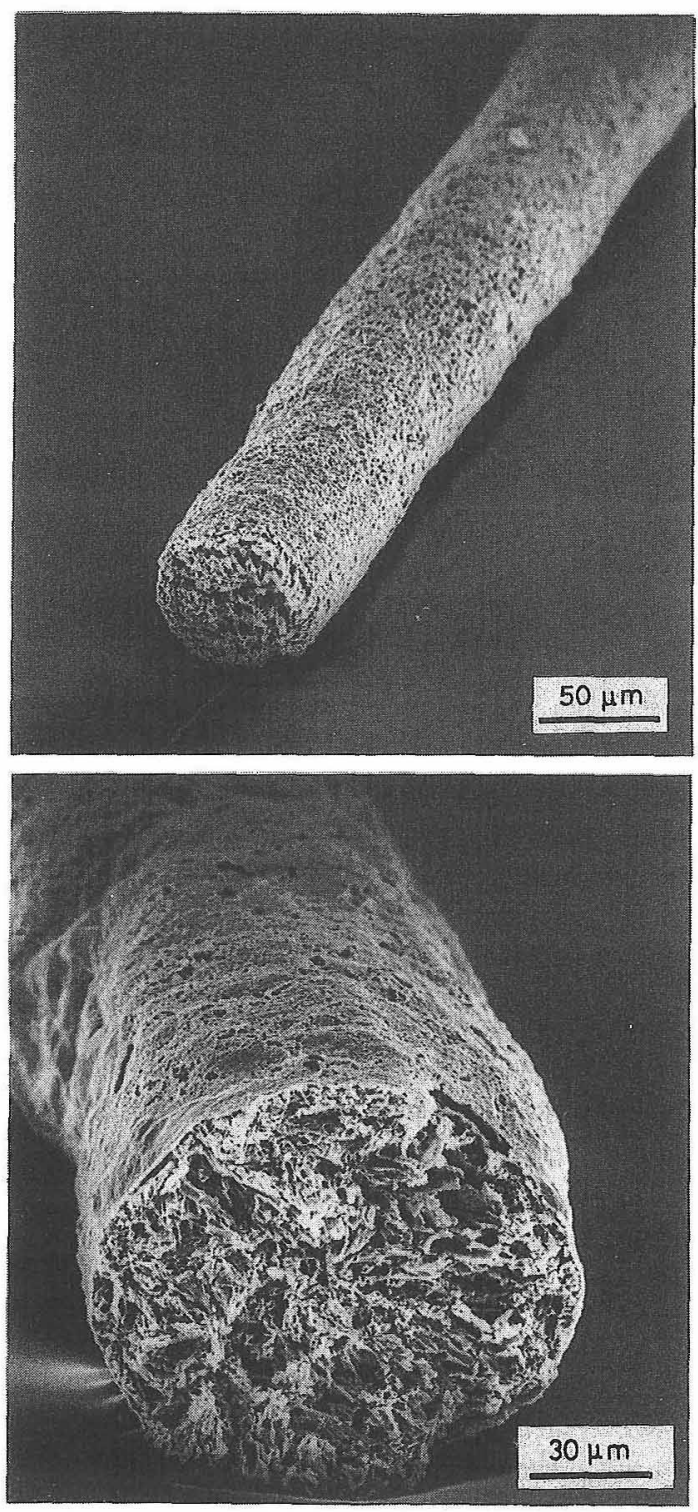

Fig. 9. SEM micrographs of ceramic fibers. The fibers were heated from room temperature to $500^{\circ} \mathrm{C}$ at a rate of $5^{\circ} \mathrm{C} / \mathrm{h}\left(0.0833^{\circ} \mathrm{C} / \mathrm{min}\right)$ and from $500^{\circ}$ to $900^{\circ} \mathrm{C}$ at a rate of $10^{\circ} \mathrm{C} / \mathrm{h}\left(0.167^{\circ} \mathrm{C} / \mathrm{min}\right)$. They were kept for $12 \mathrm{~h}$ and cooled in the furnace.

においても有機物の熱分解による急激な気体発生のピー クがみられる，金属酷酸塩の熱分解によって発生する気 体は， 3 種の金属酢酸塩からなるゲルの熱分解時に発生 する気体と同じく質量数 $18,28,43,44$ の化学種を含む ことが分かる。金属酢酸塩のうち, $\mathrm{Cu}\left(\mathrm{CH}_{3} \mathrm{COO}\right)_{2} \cdot \mathrm{H}_{2} \mathrm{O}$ の熱分解の場合には他の金属酢酸塩とは異なり, $\mathrm{COOH}$ と $\mathrm{CH}_{3} \mathrm{COOH}$ の生成が確認されるが, $\left(\mathrm{CH}_{3}\right)_{2} \mathrm{CO}$ の生成は確認されない。

\section{5 セラミックファイバーの微細構造}

図 9 に昇温速度 $0.0833^{\circ} \mathrm{C} / \mathrm{min}\left(5^{\circ} \mathrm{C} / \mathrm{h}\right)$ で室温より 

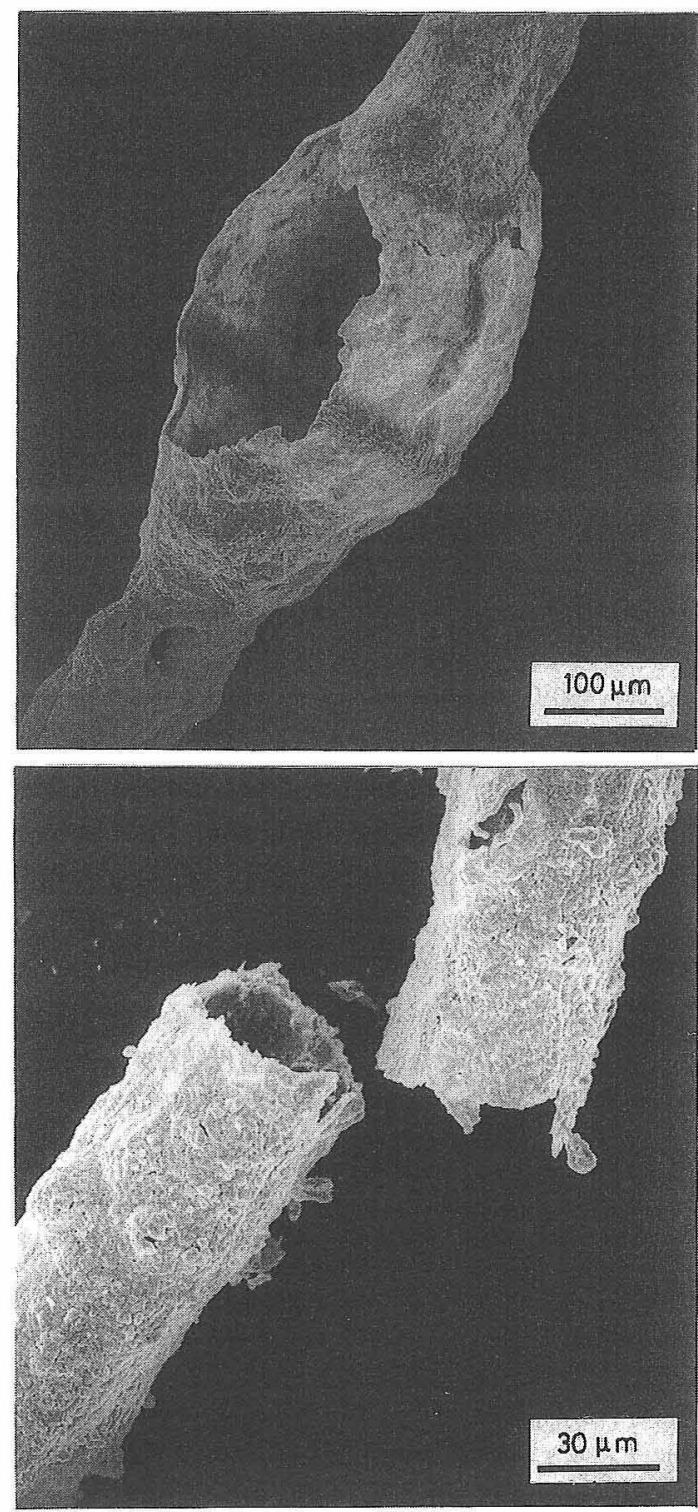

Fig. 10. SEM micrographs of ceramic fibers. The fibers were heated from room temperature to $900^{\circ} \mathrm{C}$ at a rate of $5^{\circ} \mathrm{C} / \mathrm{min}$, kept for $12 \mathrm{~h}$ and cooled in the furnace.

$500^{\circ} \mathrm{C}$ まで加熱し，その後昇温速度 $0.167^{\circ} \mathrm{C} / \mathrm{min}\left(10^{\circ} \mathrm{C} /\right.$ h) で $900^{\circ} \mathrm{C}$ まで加熱， 12 時間保持したのち炉中放冷し て得られたセラミックファイバーの走査型電子顕微鏡 (SEM) 写真を示す. 図 10 に昇温速度 $5^{\circ} \mathrm{C} / \mathrm{min}$ で室 温より $900^{\circ} \mathrm{C}$ まで加熱し，12 時間保持したのち炉中放 冷して得られたセラミックファイバーの SEM 写真を示 す.これらの写真を比較すると，大きな昇温速度で加熱 した場合，ゲルファイバーは焼成時に発生する気体のた めに膨張し, 中空構造となるが, 昇温速度を $0.1^{\circ} \mathrm{C} / \mathrm{min}$ 程度にすれば, 発泡による顕著な形状変化 をうけずに結晶相が析出し，中実のファイバーが得られ
ることが分かる。

\section{4. 考察}

\section{1 ゲルの構造}

金属酢酸塩の水溶液を $60^{\circ} \mathrm{C}$ で濃縮してつくったゲル にメタロキサン結合がなく，代わりに，カルボキシル基 とメチル基が認められることは，金属イオン間を酢酸基 が架橋することによってゲル中にネットワーク構造が構 成されていることを示している。

この考え方はゲルの熱分析によっても支持される。熱 重量测定では $220^{\circ} \mathrm{C}$ までに $6.4 \%$ の重量堿少があり, 全重量損失は $49.9 \%$ に達することを示している. $220^{\circ} \mathrm{C}$ 以下での重量損失は，赤外吸収と発生気体の測定 から，その大部分は水の脱離によることが明らかである。 そこで, $220^{\circ} \mathrm{C}$ 以下の応はすべて水の脱離であると仮 定し，かつ，完全に水を除去した乾燥ゲルを作製できた と仮定すると，この仮想的な乾燥ゲルが熱分解によって 失う重量は $46.5 \%$ であると見積もることができる $[(49.9$ $-6.4) \div(100-6.4)=0.465]$. 一方，酎酸塩ゲルの熱分 解が以下に示すような酢酸基の分解反応であると仮定し た場合，その重量損失は $49.6 \%$ 亡計算できる。

$$
\begin{aligned}
& \mathrm{Y}\left(\mathrm{CH}_{3} \mathrm{COO}\right)_{3}+2 \mathrm{Ba}\left(\mathrm{CH}_{3} \mathrm{COO}\right)_{2} \\
& \quad+3 \mathrm{Cu}\left(\mathrm{CH}_{3} \mathrm{COO}\right)_{2} \longrightarrow \mathrm{YBa}_{2} \mathrm{Cu}_{3} \mathrm{O}_{7}
\end{aligned}
$$

この值は上の $46.5 \%$ の值とほぼ一致しているが,これ はゲル中に出発物質に含まれる酢酸基のほぼすべてが残 留していることを示唆している．このことはゲル骨格が 酢酸基の架橋によってできているという推測が妥当であ ることを間接的に支持する。たたし，2つの見積もりの うち，後者ではゲル中に含まれるアンモニウムイオンの 重量は考慮されていないが，加えたアンモニアのすべて がゲル中に残っていたとしてもその質量はゲル全体の $2 \%$ 以下であるので, 大きな誤差を与えるものではない,

\section{2 ゲルの熱分解}

ゲルの加熱処理によって $\mathrm{YBa}_{2} \mathrm{Cu}_{3} \mathrm{O}_{7-y}$ セラミックス が生成するまでに起こる反応は次の 5 段階に分けられる.

(1) 吸着水の脱離 (室温 $220^{\circ} \mathrm{C}$ )

（2）銅イオンに結合する酢酸基及びアンモニウムイ

$$
\text { オンの分解 }
$$

$\left(220^{\circ} \sim 240^{\circ} \mathrm{C}\right)$

（3）バリウムイオンに結合する酢酸基の分解 $\left(300^{\circ} \sim 380^{\circ} \mathrm{C}\right)$

（4）イットリウムイオンに結合する酢酸基の分解

$$
\left(380^{\circ} \sim 430^{\circ} \mathrm{C}\right)
$$

（5）反応生成物間の反応

$\left(430^{\circ} \mathrm{C}\right.$ 以上)

\section{これらの反応をまとめて表 2 に示す。}

（1）の段階は吸着水の脱離である. 熱分析における $6.4 \%$ 重量損失及び $85^{\circ} \mathrm{C}$ の吸熱ピーク，赤外吸収ス ペクトルにおける水の吸収ピークの減少, 発生気体の分 析における生成気体中の水の存在から，吸着水の脱離反 
Table 2. Thermal decomposition of the metal acetate gel.

\begin{tabular}{|c|c|c|c|}
\hline step & Temp. $/{ }^{\circ} \mathrm{C}$ & reaction & gas composition \\
\hline I & R.T. -220 & Elimination of $\mathrm{H}_{2} \mathrm{O}$ & $\mathrm{H}_{2} \mathrm{O}$ \\
\hline $\mathrm{II}^{*}$ & $220-300$ & $\begin{array}{l}\text { Thermal decomposition } \\
\text { of acetate ions bonding } \\
\text { with copper ions }\end{array}$ & $\begin{array}{l}\mathrm{CH}_{3} \mathrm{CO}, \mathrm{CO}_{2} \text { or } \\
\mathrm{N}_{2} \mathrm{O}, \mathrm{COOH}, \mathrm{CO}, \\
\mathrm{CH}_{3} \mathrm{COOH}, \mathrm{H}_{2} \mathrm{O}\end{array}$ \\
\hline III & $300-380$ & $\begin{array}{l}\text { Thermal decomposition } \\
\text { of acetate ions bonding } \\
\text { with barium ions }\end{array}$ & $\begin{array}{l}\mathrm{CH}_{3} \mathrm{CO}, \mathrm{CO}_{2} \\
\left(\mathrm{CH}_{3}\right)_{2} \mathrm{CO}, \mathrm{CO}, \\
\mathrm{H}_{2} \mathrm{O}, \mathrm{COOH}\end{array}$ \\
\hline IV & $380-430$ & $\begin{array}{l}\text { Thermal decomposition } \\
\text { of acetate ions bonding } \\
\text { with yttrium ions }\end{array}$ & $\begin{array}{l}\mathrm{CH}_{3} \mathrm{CO}, \\
\left(\mathrm{CH}_{3}\right)_{2} \mathrm{CO}\end{array}$ \\
\hline V & about 800 & $\begin{array}{l}\text { Release of } \mathrm{CO} \text { from } \\
\mathrm{BaCO}_{3}\end{array}$ & $\mathrm{CO}$ \\
\hline
\end{tabular}

* This reaction causes bloating of the gel during heat treatment.

応が進行していることが分かる。

（2）の段階は銅イオンに結合する有機物の分解であ る. 熱分析では最大の重量損失及び $240^{\circ} \mathrm{C}$ の大な発 熱ピークがみられる.X線回折パターンでは $220^{\circ}, 240$ ${ }^{\circ} \mathrm{C}$ において $\mathrm{Cu}$ と $\mathrm{Cu}_{2} \mathrm{O}$ の生成が確認される。発生気 体の分析では約 $240^{\circ} \mathrm{C}$ に気体発生の最大のピークがみ られ, 質量分析の結果から気体の成分が $\mathrm{H}_{2} \mathrm{O}, \mathrm{CO}$, $\mathrm{CH}_{3} \mathrm{CO}, \mathrm{CO}_{2}$ あるいは $\mathrm{N}_{2} \mathrm{O}, \mathrm{COOH}, \mathrm{CH}_{3} \mathrm{COOH}$ であ ることが確認された。 $\mathrm{Cu}\left(\mathrm{CH}_{3} \mathrm{COO}\right)_{2}$ の熱分解に特有な 現象である $\mathrm{CH}_{3} \mathrm{COOH}$ の生成が確認されることから， この段階で起こる反応は銅イオンに結合する有機物の分 解であると考えられる. また, 後述の理由により，この 段階でアンモニウムイオンの分解も起こっていると考え られる。これらの反応はまた, 銅イオンに結合する酢酸 基の熱分解による気体の発生がゲルの発泡を引き起こし ていることも意味する。

（3）の段階はバリウムイオンに結合する有機物の分 解である。熱分析では $300^{\circ}, 380^{\circ} \mathrm{C}$ における発熱ピーク と $300^{\circ} \sim 380^{\circ} \mathrm{C}$ での重量損失がみられる。 X線回折パ ターンでは $\mathrm{Ba}(\mathrm{OH})_{2}$ と $\mathrm{BaCO}_{3}$ の生成が確認され, 赤 外吸収スペクトルからも $380^{\circ} \mathrm{C}$ で炭酸イオンの生成が 認められる．これらのデータは $300^{\circ} \sim 380^{\circ} \mathrm{C}$ でバリウム イオンに結合する䣷酸基が熱分解することを示してい る. 更に, 発生気体の分析では $340^{\circ} \mathrm{C}$ に気体発生のピ一 クが観測される。質量分析より，この段階で発生する気 体に含まれる化学種は $18,28,43,44,45,58$ の質量数 を持つことが分かったが, そのうちの質量数 44 の化学 種は $\mathrm{CO}_{2}$ であると考えるのが妥当である。銅化合物は 既に分解しており，銅に結合しているアンモニウムイオ ンはゲルから脱離していると考えられるためである. アンモニウムイオンが銅に結合すると考える根拠は,
出発溶液の $\mathrm{pH}$ 調整のためにアンモニア水を加えると 溶液の青色が変化することと, $\mathrm{pH}$ 值が低いと銅が $\mathrm{Cu}\left(\mathrm{CH}_{3} \mathrm{COO}\right)_{2} \cdot \mathrm{H}_{2} \mathrm{O}$ として析出することである.したがっ て,この段階で発生する気体は $\mathrm{CH}_{3} \mathrm{CO}, \mathrm{CO}_{2},\left(\mathrm{CH}_{3}\right)_{2} \mathrm{CO}$ 上少量の $\mathrm{H}_{2} \mathrm{O}, \mathrm{CO}, \mathrm{COOH}$ からなるこが分かる.以 上のことから, $300^{\circ} \sim 380^{\circ} \mathrm{C}$ の温度域で進行する反応は バリウムイオンに結合する有機物の分解反応之, $\mathrm{Cu}$, $\mathrm{Cu}_{2} \mathrm{O}$ が $\mathrm{CuO}$ に酸化される反応であると考えられる。 アセトンの発生もバリウムイオンに結合する酢酸基の分 解の結果として理解される. バリウムの有機酸塩の熱分 解でケトンが発生することは既に知られている ${ }^{14)}$.

（4）の段階はイットリウムイオンに結合する有機物 の分解である. 熱分析では $430^{\circ} \mathrm{C}$ に最大の発熱ピーク

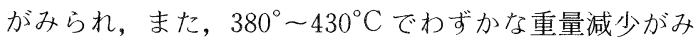
られる. 試料の重量はこの後 $900^{\circ} \mathrm{C}$ までほとんど減少 しない. $430^{\circ} \mathrm{C}$ の赤外吸収スペクトルではカルボキシル 基の吸収がほぼ消滅する。 $430^{\circ} \mathrm{C}$ の X線回折パターンで は $\mathrm{Ba}(\mathrm{OH})_{2}$ のピークが消滅し, $\mathrm{BaCO}_{3}$ のピーク強度の 増大が認めら北る。発生気体の分析では, $394^{\circ} \mathrm{C}$ につ の気体発生のピークのうち最後で最小のピークが観察さ れ，クロマトグラムより気体は $\mathrm{CH}_{3} \mathrm{CO} と\left(\mathrm{CH}_{3}\right)_{2} \mathrm{CO}$ の混合物であることが分かる，これらのことより，ゲル 中の酢酸基は $430^{\circ} \mathrm{C}$ でほぼすべて分解すると考えられ る.したがって，イットリウムイオンに結合する有機物 はすべて分解していると考えられるが，X線回折パター ンでは $\mathrm{Y}_{2} \mathrm{O}_{3}$ のピークは $450^{\circ} \mathrm{C}$ になってもわずかにしか 現れない. しかし，これは $\mathrm{Y}_{2} \mathrm{O}_{3}$ が十分に結晶化してい ないことによって説明される. $430^{\circ} \mathrm{C}$ 以上の高温域では ほとんど重量減少がみられないという熱分析のデータ, $430^{\circ} \mathrm{C}$ でカルボキシル基が消隇するという赤外吸収の データを考えるとこの温度域でイットリウムイオンに結 合している酢酸基は既に分解しているはずである．赤外 吸収スペクトル上で $\mathrm{Y}_{2} \mathrm{O}_{3}$ の吸収は $1470,1380 \mathrm{~cm}^{-1}$ の ピークと $600 \mathrm{~cm}^{-1}$ 以下の幅広い吸収帯としてあらわれ るが， $450^{\circ} \mathrm{C}$ の赤外吸収スペクトルにおける $1500 \mathrm{~cm}^{-1}$ 付近のショルダーは $\mathrm{Y}_{2} \mathrm{O}_{3}$ の存在に起因するものであ り,また $600 \mathrm{~cm}^{-1}$ 以下の吸収帯は $\mathrm{Y}_{2} \mathrm{O}_{3}$ も含んだメ夕 ロキサン結合を示すものと考えられる．イットリウムイ オンに結合した酢酸基の分解温度は明確にはわからない が，最大の発熱ピークがあることから $430^{\circ} \mathrm{C}$ 付近であ ろうと推定される．既に銅，バリウムイオンに結合する 有機物は分解しているため, この発熱はイットリウムイ オンに結合する有機物の分解によるものと考えられるか らである。したがって， $430^{\circ} \mathrm{C}$ では，試料は主として $\mathrm{CuO}, \mathrm{BaCO}_{3}, \mathrm{Y}_{2} \mathrm{O}_{3}$ からなり, 少量の $\mathrm{Cu}_{2} \mathrm{O}, \mathrm{Ba}(\mathrm{OH})_{2}$ や有機物を含む混合物になっていると考えられる。

（3）の段階亡（4）の段階での反応の差異は発生気 体中の $\mathrm{CO}_{2}$ の存在である。この差異は $\mathrm{Ba}(\mathrm{OH})_{2}$ が $\mathrm{CO}_{2}$ 
を吸収して $\mathrm{BaCO}_{3}$ に変化したと考えることによって説 明される。X線回折パターンや赤外吸収スペクトルにお ける $\mathrm{BaCO}_{3}$ の増加がそれを裏付けている. 更に, この 推測によって熱分析と発生気体分析の TG 曲線の差異 も説明される.すなわち熱分析は空気中で, 発生気体の 分析はへリウム雾用気中で行われたため, 後者では有機 物の然焼による $\mathrm{CO}_{2}$ の発生がなく, 吸収される $\mathrm{CO}_{2}$ の 量が少ないので, $430^{\circ} \mathrm{C}$ 以上でも重量が減少し続けると 解釈される。

（5）の最終段階では，反応生成物間の反応がおこっ て YBCO セラミックスが生成する。発生気体の分析で は約 $800^{\circ} \mathrm{C}$ に CO の発生を示すわずかなピークがみら れるが、この $\mathrm{CO}$ は $\mathrm{BaCO}_{3}$ から遊離したものである。 同時に $800^{\circ} \mathrm{C}$ の赤外吸収スペクトルでは $1500 \mathrm{~cm}^{-1}$ 付 近のショルダーが消滅し, $\mathrm{Y}_{2} \mathrm{O}_{3}$ の減少も観察される. $950^{\circ} \mathrm{C}$ における赤外吸収スペクトルから, 炭酸イオンと メタロキサン結合の吸収が減少していることが分かる. この赤外吸収スペクトルから試料は $\mathrm{YBa}_{2} \mathrm{Cu}_{3} \mathrm{O}_{7-y}$, $\mathrm{CuO}, \mathrm{BaCO}_{3}, \mathrm{Y}_{2} \mathrm{O}_{3}$ の混合物であることが推測される。

\section{3 ゲルの発泡の抑制}

以上に記したゲルの熱分解過程の解析によると, 焼成 時のゲルの軟化と発泡は主として銅イオンに結合する有 機物の分解によって生じることが分かる。ゲルは $200^{\circ}$ $\sim 300^{\circ} \mathrm{C}$ で軟化し, 発生した気体によって膨張する。し たがって,この温度域での急激な気体の発生を抑制すれ ば，ゲルの著しい発泡を避けることができると推察され る. $300^{\circ} \mathrm{C}$ 以上の高温ではゲルは再び硬化するので, 気 体が発生してもゲルの発泡にはほとんど影響しないはず である。

ゲルの発泡を少なくするための方法として加熱処理の 改善が考えられる. $0.1^{\circ} \mathrm{C} / \mathrm{min}$ 程度の小さな昇温速度 で焼成を行えば, 気体の発生速度が小さくなるので発泡 を最小限に抑えることができると思われる。実際, 増田 亡建石はこのような焼成条件のもとで金属アルコキシド を出発原料とする $\mathrm{YBa}_{2} \mathrm{Cu}_{3} \mathrm{O}_{x}$ セラミックファイバーの 作製を報告している ${ }^{10)}$.もう一つの方法として考えられ るのは出発物質として酢酸塩以外の銅化合物を使用する ことである. $300^{\circ} \mathrm{C}$ 以上で分解するような銅化合物を使 用すれば，ゲルの発泡を抑制した焼成ができる可能性が ある、ただし，この方法では，溶液のゲル化条件などを 再び研究することが必要となる。

本研究で著者らは前者の方法を試みた。すなわち昇温 速度を $0.0833 \sim 0.167^{\circ} \mathrm{C} / \mathrm{min}\left(5 \sim 10^{\circ} \mathrm{C} / \mathrm{h}\right)$ と比較的低 速に設定し, 単位時間あたりの気体発生量を抑えること により,ゲルの発泡を抑制し緻密・中央なセラミック ファイバーの作製を試みた。その結果，金属酢酸塩を出
発原料とする系でも中実構造を持つセラミックファイ バーが作製できることを確認した。

\section{5. 総 括}

$\mathrm{YBa}_{2} \mathrm{Cu}_{3} \mathrm{O}_{7-y}$ 超伝導セラミックスの前駆体である金 属酢酸塩ゲルの構造を調べた。ゲルは，金属イオン間を 酢酸基が架橋したネットワーク構造を持っているものと 推測した. また，ゲルの加熱時に起こる反応を追求し， 水の脱離, 銅イオンに結合する有機物の分解反応，バリ ウムイオンに結合する有機物の熱分解，イットリウムに 結合している有機物の熱分解, $\mathrm{CuO}, \mathrm{BaCO}_{3}, \mathrm{Y}_{2} \mathrm{O}_{3}$ 混 合物の反応による $\mathrm{YBa}_{2} \mathrm{Cu}_{3} \mathrm{O}_{7-y}$ セラミックスの生成が 順次起こることを示した。 また，焼成中のゲルの発泡は $200^{\circ} \sim 300^{\circ} \mathrm{C}$ の温度域の気体発生速度を小さくすること により抑制できると考え，昇温速度を小さくすることに よって, 中実のセラミックファイバーが得られることを 示した。

謝辞 本研究は文部省科学研究費補助金重点領域研究「新 超伝導体の化学」(課題番号 01645004) 及び(財) 日本板硝子材 料工学助成会第 11 回研究助成の援助のもとに行った。ここに謝 意を表します。

\section{文献}

1) C. E. Rice, R. B. van Dover and G. J. Fisanick, Appl. Phys. Lett., 51, 1842-44 (1987).

2) T. Kumagai, H. Yokota, K. Kawaguchi, W. Kondo and S. Mizuta, Chem. Lett., 1645-46 (1987).

3) T. Monde, H. Kozuka and S. Sakka, Chem. Lett., 287 (1988).

4) S. Kramer, K. Wu and G. Kordas, Mater. Res. Soc, Symp. Proc., 99, 323-26 (1988).

5) H. Nasu, S. Makida, T. Imura and Y. Osaka, J. Mater. Sci. Lett., 7, 858-60 (1988).

6) F. Uchikawa and J.D. Mackenzie, J. Mater. Res., 4, 787-94 (1989).

7) E. J.A. Pope and J. D. Mackenzie, in "High Temperature Superconductors II", Ed. by D.W. Capone II, W. H. Butler, B. Batlogg and C.W. Chu, Materials Research Society, Pittsburgh, 1988, pp.93-96.

8) R. M. Laine, K. A. Youngdahl, W. M. Carty, G. C. Stangle, C. Han, R. A. Kennish, S. McElhaney, T. K. Yin, T. Yogo and M. Sarikawa, in "Ceramic Superconductors II", Ed. by M.F. Yan, The American Ceramic Society, Ohio (1988) pp.450-63.

9) H. Konishi, T. Takamura, H. Kaga and K. Katsuse, Jpn. J. Appl. Phys., 28, L241-43 (1989).

10）增田喜男，建石 剛, 粉体および粉末治金，35，865-69 (1988).

11) H. Zhuang, H. Kozuka and S. Sakka, Jpn. J. Appl. Phys., 28, L1805-08 (1989).

12) S. Sakka, H. Kozuka and T. Umeda, Seramikkusu Ronbunshi, 96, 468-70 (1988).

13) T. Umeda, H. Kozuka and S. Sakka, Adv. Ceram. Mater. , 3, 520-22 (1988).

14）横田 洋, 熊谷俊弥, 水田 進, 熱測定, 15, 97-102 (1988). 